DOI 10.37882/2500-3682.2021.03.23

\title{
ПРОБЛЕМЫ ОРГАНИЗАЦИИ СПОРТИВНО-МАССОВЫХ МЕРОПРИЯТИЙ В РАМКАХ РУССКО-КИТАЙСКОГО СОТРУДНИЧЕСТВА С ТОЧКИ ЗРЕНИЯ «ОДИН ПОЯС, ОДИН ПУТЬ»1
}

\section{PROBLEMS OF ORGANIZING SPORTS EVENTS WITHIN THE FRAMEWORK OF RUSSIAN-CHINESE COOPERATION FROM THE POINT OF VIEW OF "ONE BELT, ONE ROAD"}

\section{Zhang Wei Ning Wenjing}

Summary: The article presents the results of a study aimed at considering the possibilities of the most effective use of the "One Belt, One Road» strategy in the organization of sports events within the framework of Russian-Chinese cooperation. The study analyzes the current situation in the area under study, identifies current obstacles to achieving the goal of the «Belt and Road» initiative-increasing cultural exchange between Russia and China, and identifies ways to eliminate them. The results of the study can be used for further development in the organization of sports events that will act as a carrier of the Sino-Russian friendship within the framework of the «One Belt, One Road» concept, contributing to the increase in national cultural exchanges between China and Russia.

Keywords: mass sports events, strategy of Russian-Chinese cooperation, development problems, cultural exchange.

\section{Введение}

$\mathrm{O}$ бращение к теме настоящего исследования неслучайны и обусловлены возможностями, предоставляемые стратегией «Один пояс, один путь» (Россия - Китай), позволяющей осуществлять культурный обмен. В частности, в настоящее время отмечается недостаточность обмена опытом организации мероприятий в области культуры и спорта, в виду того, что обе стороны по-прежнему осуществляют деятельность в названных отраслях под девизом «закрыть дверь и сделать самому». Такая ситуация негативно отражается на развитии культурного обмена между странами, ограничивая рост новых коннотаций спортивной дипломатии в стратегию «Один пояс, один путь» не позволяя иннова-

\author{
Чжан Вэй \\ старший преподаватель, Хэйхэский университет, Хэйхэ \\ (KHP), \\ zhangwei-5688679@163.com \\ Нин Вэньцзин \\ nрофессор, Хэйхэский университет, Хэйхэ (КНР), \\ ningwenjing123@163.com
}

Аннотация: В статье представлены результаты исследования, целью которого стало рассмотрение возможностей максимально эффективного использования стратегии «Один пояс, один путь» в организации спортивно-массовых мероприятий в рамках русско-китайского сотрудничества. В ходе исследования подвергнута анализу сложившаяся на сегодняшний день ситуация в изучаемой области, выявлены текущие препятствия на пути к достижению цели инициативы «Пояса и пути» - увеличение культурного обмена между Россией и Китаем, и обозначены направления их устранения. Результаты исследования могут быть использованы для дальнейшего развития в организации спортивных мероприятий, которые выступят в качестве носителя китайско-российской дружбы в рамках концепции «Один пояс, один путь», способствуя увеличению национального культурного обменам между Китаем и Россией.

Ключевые слова: спортивно-массовые мероприятия, стратегия русско-китайского сотрудничества, проблемы развития, культурный обмен.

ционному проекту развиваться на благо двух народов. В настоящем исследовании остановимся более подробно на рассмотрении возможностей максимально эффективного использования стратегии «Один пояс, один путь» В организации спортивно-массовых мероприятий в рамках русско-китайского сотрудничества.

\section{Теоретический анализ проблемы исследования}

Первоначально, следует отметить, что на сегодняшний день, в ходе реализации стратегии «Один пояс, один путь», Китай занимает достаточно низкие позиции в рейтинге международных спортивных коммуникаций. Незначительные улучшения отмечаются в последние годы, что подтверждается количеством проведенных

Данная статья является результатом научно-исследовательского проекта 2018 г. провинциальных вузов Хэйлунцзяна «Исследование путей и стратегии развития китайских и российских спортивно-массовых мероприятий в провинции Хэйлунцзян». Номер проекта: 2018-KYYWF-1280. 
спортивных мероприятий, которые при правильной организации могли бы способствовать трансляции имиджа спортивной культуры Китая во внешний мир путем создания модели культурного обмена между Китаем и странами-участницами инициативы «Пояса и пути».

На сегодняшний день китайско-российские культурные обмены, реализуемые в рамках стратегии «Один пояс, один путь» все еще обладают значительной «зависимостью». Большинство организаций занятых в реализации российско-китайского культурного обмена выступают в роли основных носителей спортивно-культурных традиций, трансляция которых в определенной степени ограничены [5, с.192]. Путем планирования и непосредственной организации массовых спортивных мероприятий между Китаем и Россией с первоочередной целью «образование связей между представителями двух держав» можно существенно снизить или полностью избавиться от «зависимости», использовав модель рыночных взаимоотношений для расширения взаимовыгодных культурно-экономических обменов в рамках вышеназванной стратегии.

С точки зрения рассматриваемой инициативы в настоящий момент общая тенденция массовых спортивных мероприятий между Китаем и Россией относительно хорошая и характеризуется устойчивым ростом проявляемых с обеих сторон инициатив. Начиная с китайско-российского соревнования по байдарочной гребле, проведенной в городе Фуюань в августе 2015 года, и первого китайско-российского велосипедного турнира, проведенного в городе Суйфэньхэ провинции Хэйлунцзян (КНР), и Владивостоке (РФ) в 2019 году, на регулярной основе между двумя странами проводятся дружественные баскетбольные встречи, международные футбольные матчи, автомобильные гонки вдоль границ реки Амур, молодежные шахматные турниры, китайскороссийский трансграничный марафон «1+1», соревнования по боксу, соревнования по парусному спорту, зимние юношеские игры, экстремальные соревнования на резиновых лодках и т.д.

Подобные соревнования были проведены в г. Биробиджане, в г. Хэйхэ провинции Хэйлунцзян, Амурской области, в г. Суйфэньхэ, во Владивостоке, в г. Мишань, в г. Харбин, в г. Фуюань, в г. Муданьцзян, в г. Самаре, в г. Благовещенске, в г. Хабаровске, в г. Циньхуандао, в г. Пекине и др. Прошедший 2020 год стал годом обмена СМИ между Китаем и Россией. Благодаря возможностям, предоставляемым инициативой «Один пояс, один путь», китайско-российские массовые спортивные мероприятия продолжают планироваться и организовываться, тем самым оказывая положительное влияние на развитие культурного обмена между двумя державами - Россией и Китаем.
Далее более подробно остановимся на трудностях и препятствиях, с которыми сталкиваются Россия и Китай в ходе реализации стратегических задач инициативы «Пояса и пути».

1. Недостаточная узнаваемость бренда спортивных мероприятий.

Согласно концепции «Один пояс, один путь», массовые спортивные мероприятия в Китае и России разнообразны и охватывают различные возрастные группы: детей, людей молодого и среднего возраста, а также пожилых представителей двух стран. Тем не менее, анализируя массовые спортивные мероприятия, проведенные в рамках культурного сотрудничества между Россией и Китаем за последние годы, можно сказать, что основная цель, а именно привлечение большого количества граждан обеих стран к занятиям спортом, еще не достигнута. Наблюдаемый эффект недостаточен, и большинство людей до сих пор не осознают значимость массовых спортивных мероприятия между Китаем и Россией, с точки зрения устойчивого развития культурного взаимообогащающего обмена.

2. Несбалансированное развитие массовых спортивных мероприятий.

Согласно концепции «Один пояс, один путь», массовые спортивные мероприятия между Китаем и Россией продолжают реализовываться. Однако на пути к их реализации встречается множество дисбалансов, в частности, между проектом и региональной неустойчивостью. Первый дисбаланс в основном проявляется в том, что фехтование, гимнастика, настольный теннис и ряд других массовых спортивных мероприятий составляют относительно большую долю, в то время как другие остаются «в тени», что приводит к отсутствию коннотации спортивных событий Китая и России и оказывает негативное влияние на общий прогресс спортивной культуры стран-участниц инициативы «Пояса и пути». В основном благодаря влиянию географических и исторических факторов проведение массовых спортивных мероприятий происходит в провинции Хэйлунцзян и в городах Дальнего Востока России значительно чаще по сравнению с другими регионами стран [1, с.336], в которых массовые спортивные мероприятия проводятся в меньшем количестве, а зачастую и вовсе не проводятся.

\section{3. Слабый фундамент обмена народной культуры.}

За почти 100 лет систематически осуществляемых обменов между Россией и Китаем были созданы глубокие культурные связи. Однако в рамках концепции «Один пояс, один путь» культурная основа, необходимая для реализации массовых спортивных мероприятий остается достаточно неустойчивой. Из-за ограниченности 
мест, времени и ряда других факторов проводимые в рамках инициативы «Пояса и пути», не способны удовлетворить потребности в области физической культуры и спорта большинство людей. Сложившаяся ситуации не только повлияло на быстрое и качественное развитие массовых спортивных мероприятий, осуществляемых усилиями двух стран, но и скрыло большое число конфликтов, вызванных культурными различиями.

Вскрытые недостатки и препятствия на пути культурного обмена между Россией и Китаем, позволили сформулировать основные положения стратегии развития проекта «Один пояс, один путь» в контексте проведения массовых спортивных мероприятий.

Первое, на что стоит обратить внимание, это усилия, прилагаемые к развитию бренда массовых спортивных мероприятий. В соответствии с концепцией «Один пояс, один путь» предпосылкой для долгосрочного развития любого спортивного мероприятия является получение признания со стороны масс, которые обладают такими характеристиками, которые разительно отличаются от других подобных мероприятий, привлекая повышенное внимание и вовлекая большее число участников. Отмеченное позволит постепенно приобрести более стабильную коммерческую позицию.

Исходя из сказанного, для развития бренда массовых спортивных мероприятий, осуществляемых в рамках стратегии «Один пояс, один путь», организаторам следует уточнить характер, характеристики и недостатки китайских и российских спортивных мероприятий, удовлетворить потребности групп и целенаправленно скорректировать планы планирования спортивных мероприятий, в соответствии с общей тенденцией развития индустрии массового спорта, темпами её становления, регулируя рыночное позиционирование спортивных мероприятий и стимулируя устойчивое развитие брендов спортивных мероприятий [3, с.75].

Глубокая культурная коннотация является основой для развития бренда массовых спортивных мероприятий в Китае и России в рамках концепции «Один пояс, один путь». С целью усиления и стимулирования развития массовых спортивных мероприятий в Китае и России, обе стороны-участницы должны глубже изучить спортивную культуру стран.

В качестве примера можно привести китайско-российские виды спорта на резиновых лодках. В 2015 году в г. Мохэ открылся экстремальный китайско-российский турнир на резиновых лодках. Двадцать игроков пересекли пограничную реку и завершили соревнования от Тунцзян до Фуюаня. Проведение соревнований на резиновых лодках в России имеет почти столетнюю историю, а в Китае данный вид спорта родился на сотни лет раньше. Однако этот обычай больше не использовался на массовых спортивных мероприятиях в Китае и культивировался как отличительный бренд массовых спортивных мероприятий.

Показательный пример свидетельствует о необходимости разработки производных продуктов, необходимых для массовых спортивных мероприятий, исходя из требований распространения спортивных концепций, и заручившись поддержкой профессионалов при условии обеспечения нормального развития массовых спортивных мероприятий. Деривативы необходимы для Китая и России. Посредством разработки производных мероприятий можно изучать культуру проведения массовых спортивных мероприятий в Китае и России, тем самым укрепляя основу для их культивирования.

Второе - соблюдение баланса ресурсов, ориентированных на развитие спортивных мероприятий. Согласно концепции «Один пояс, один путь», связи между людьми являются основой и предпосылкой для развития массовых спортивных мероприятий между Китаем и Россией. Таким образом, в соответствии с «Видениями и действиями по совместному строительству экономического пояса Шелкового пути и морского Шелкового пути XXI века», совместно изданным Комиссией по развитию и реформам Китая, Министерством иностранных дел и Министерством торговли, массовые спортивные мероприятия, проводимые между Россией и Китаем, должны быть включены в прогностику исследований потребностей участниц проектов «План связи между людьми» [4, с.61]. Кроме того, опираясь на то, что Китай и Россия являются мощными державами, должны быть направлены усилия для привлечения широких слоев населения двух стран для дальнейшего продвижения китайскороссийских спортивных и культурных обменов, а также развития многонациональных массовых спортивных мероприятий.

Tретье - укрепление основ народной культуры. Китайско-российские массовые спортивные мероприятия в рамках концепции «Один пояс, один путь» имеют множество функций, таких как стимулирование развития экономического пояса Шелкового пути, укрепление репутации Китая и сохранение китайско-российской дружбы. В контексте сказанного, с целью укрепления народно-культурной основы массовых спортивных мероприятий, все населенные пункты должны стремиться к поддержке широких масс [2, с.148]. Опираясь на вышеназванное и используя превосходные ресурсы культуры в проведении массовых спортивных мероприятий в Китае и России, следует приложить дополнительные усилия для того, чтобы представители двух стран могли в полной мере почувствовать национальную самобытность, живой интерес и культурную насыщенность от участия в спортивных мероприятиях, тем самым акти- 
визируя спортивного дух граждан Китая и России. В то же время, основанное на тесной взаимосвязи между народной культурой и этническими группами, проведение массовых спортивных мероприятий подобных автомобильному туру по Китаю и России, способно не только удовлетворить потребности в двигательной активности граждан России и Китая, но и создать хорошую культурную основу для формирования взаимопонимания представителей двух стран.

\section{Выво $\Delta ы$}

Подводя итог, можно сказать, что в рамках видения инициативы «Один пояс, один путь» массовые спортивные мероприятия между Китаем и Россией получили новый толчок к развитию и в настоящее время находятся в стабильной её стадии, обладая мощным потенциалом к постоянному совершенствованию. Однако, чтобы в полной мере оценить значение массовых спортивных мероприятий, реализуемых между Китаем и Россией в рамках стратегии «Один пояс, один путь», следует подвергнуть детальному анализу этапы и имеющийся потенциал проводимых и планируемых массовых спортивных мероприятий с точки зрения политических, культурных и экономических аспектов. Следует ориентироваться в большей степени на культуру и традиции представителей обеих стран с установлением наиболее характерных видов спорта, пропагандируемых серди народных масс с целью создания нового типа массового спорта между Китаем и Россией. Сказанное будет способствовать дальнейшему развитию новых спортивных мероприятий, которые выступят в качестве носителя китайско-российской дружбы в рамках концепции «Один пояс, один путь», а также будут способствовать национальным культурным обменам между Китаем и Россией.

\section{ЛИТЕРАТУРА}

1. 冯剑.群众体育赛事从管理到治理:动力,逻辑与路径[J]. 西安体育学院学报, 2018(03):334-337.

2. 宁文晶, 张微. 黑龙江省中俄群众体育品牌赛事的培育路径及发展战略研究[J]. 黑龙江科学, 2020(11):148-149.

3. 张珊珊, 王韶峰, 隋东旭. 中俄跨界民族(赫哲族-那乃族)体育文化流变研究[J]. 体育文化导刊, 2018(006):73-77.

4. 杨光, 南尚杰, 李松洋.我国群众体育赛事治理困境与优化策略[J].体育文化导刊, 2019(008):59-64.

5. 王巍.“一带一路”背景下中俄合作的前景[J]. 学术交流, 2018(04):191-192.

() Чжан Вэ (zhangwei-5688679@163.com), Нин Вэньцзин (ningwenjing123@163.com)

Журнал «Современная наука: актуальные проблемы теории и практики» 